\title{
Correction to: Genome wide effects of oleic acid on cultured bovine granulosa cells: evidence for the activation of pathways favoring folliculo-luteal transition
}

Vengala Rao Yenuganti ${ }^{*}$, Dirk Koczan ${ }^{2}$ and Jens Vanselow ${ }^{3^{*}}$

\section{Correction to: BMC Genomics 22, 486 (2021) \\ https://doi.org/10.1186/s12864-021-07817-6}

Following publication of the original article [1], it was reported that affiliations 1 and 3 were erroneously reversed. The affiliations have been correctly assigned for Vengala Rao Yenuganti and Jens Vanselow in this Correction article and the original article has been updated.

\footnotetext{
Author details

'Animal Biology Department, School of Life Sciences, University of Hyderabad, Hyderabad, Telagana, India. Institute for Immunology, University of Rostock, 18055 Rostock, Germany. Institute of Reproductive Biology, Leibniz Institute for Farm Animal Biology (FBN), Wilhelm-Stahl-Allee 2, 18196 Dummerstorf, Germany.
}

Published online: 24 August 2021

\section{Reference}

1. Yenuganti VR, Koczan D, Vanselow J. Genome wide effects of oleic acid on cultured bovine granulosa cells: evidence for the activation of pathways favoring folliculo-luteal transition. BMC Genomics. 2021;22(1):486. https://doi. org/10.1186/s12864-021-07817-6.

The original article can be found online at https://doi.org/10.1186/s12864021-07817-6.

* Correspondence: vengal.ndri@gmail.com; vanselow@fbn-dummerstorf.de ${ }^{1}$ Animal Biology Department, School of Life Sciences, University of Hyderabad, Hyderabad, Telagana, India

${ }^{3}$ Institute of Reproductive Biology, Leibniz Institute for Farm Animal Biology (FBN), Wilhelm-Stahl-Allee 2, 18196 Dummerstorf, Germany

Full list of author information is available at the end of the article

(C) The Author(s). 2021 Open Access This article is licensed under a Creative Commons Attribution 4.0 International License, which permits use, sharing, adaptation, distribution and reproduction in any medium or format, as long as you give appropriate credit to the original author(s) and the source, provide a link to the Creative Commons licence, and indicate if changes were made. The images or other third party material in this article are included in the article's Creative Commons licence, unless indicated otherwise in a credit line to the material. If material is not included in the article's Creative Commons licence and your intended use is not permitted by statutory regulation or exceeds the permitted use, you will need to obtain permission directly from the copyright holder. To view a copy of this licence, visit http://creativecommons.org/licenses/by/4.0/ The Creative Commons Public Domain Dedication waiver (http://creativecommons.org/publicdomain/zero/1.0/) applies to the data made available in this article, unless otherwise stated in a credit line to the data. 